\title{
DYNAMIC CSF MRI FINDINGS IN THE DIAGNOSIS AND FOLLOW-UP OF ARNOLD CHIARI TYPE 1
}

\author{
ARNOLD CHİARI TIP 1 TANI VE TAKİBINDE DINAMIK BOS MRG BULGULARI
}

Begümhan BAYSAL ${ }^{1}$, Mahmut Bilal DOGAN ${ }^{1}$, Ercan BOSNAK², Mehmet Sabri GURBUZ2 ${ }^{2}$ Nejat ISIK ${ }^{2}$

\section{ABSTRACT}

AIM: Chiari malformation is a spectrum of diseases that includes different subtypes, has a wide clinical presentation, and therefore has different follow-up and treatment methods. We aimed to the compare clinical scoring systems and cerebrospinal fluid (CSF) dynamics obtained by magnetic resonance imaging (MRI) in Arnold Chiari Malformation Type-1 (CM-1) patients in the preoperative and postoperative periods.

MATERIAL AND METHOD: Twenty-one patients with CM-1 who underwent CSF MRI between January 2016 and June 2020 were included. In addition, 21 healthy volunteers were evaluated. All the patients had undergone decompression surgery due to CM-1 related symptoms. The relationship between preoperative MRI findings and clinical findings of 21 patients was evaluated. Changes in clinical and imaging findings of 21 patients who underwent surgery were compared.

RESULTS: Measurements were made just below the level of the cerebellar tonsil. CM-1 patients had higher preoperative peak positive velocity anteriorly (PPV: $6.26 \pm 2.72$ vs $3.89 \pm 1.74 \mathrm{~cm} / \mathrm{s} ; \mathrm{p}=0.001$ ) and peak negative velocity anteriorly (PNV: $-7.45 \pm 3.36$ vs $-3.61 \pm 2.65$ $\mathrm{cm} / \mathrm{s} ; \mathrm{p}=0.001)$ than healthy volunteers. Preoperative net flow in the posterior subarachnoid space of CM-1 patients was lower than healthy volunteers $(p=0.017)$. Aliasing of the reverse flow was seen in $13(62 \%)$ patients. PPV and PNV were decreased after surgery (PPV: 6.26 \pm 2.72 vs $4.73 \pm 1.94 \mathrm{~cm} / \mathrm{s}, \mathrm{p}=0.017$; PNV: $-7.45 \pm 3.36$ vs $-4.97 \pm 1.97, \mathrm{p}=0.005)$. Net Flow was increased posteriorly $(0.32 \mathrm{vs} 2.21 \mathrm{ml} / \mathrm{min} ; \mathrm{p}=0.053)$. The postoperative response was inversely proportional to the degree of tonsillar herniation. As the Asgari score of the cases increases, the Peak Positive and Negative Velocity Anterior values also increase with a statistically significant correlation ( $p=0.003 ; p=0,032$ respectively)

CONCLUSION: Our findings suggest that the determination of flow dynamics and morphology using MR imaging correlates with clinical findings and may be a useful tool in determining the need and timing of surgery.

Keywords: Chiari malformation • cerebrospinal fluid $\bullet$ phase-contrast MRI • craniocervical decompression • Asgari scoring

\section{ÖZET}

AMAÇ: Chiari malformasyonu farklı alt tipleri barındıran, geniş bir klinik prezentasyona sahip ve bu nedenle farklı takip ve tedavi yöntemleri olan bir hastalık yelpazesidir. Bu çalışmada Arnold Chiari Malformasyonu Tip-1 (CM-1) tanılı hastalarda preoperatif ve postoperatif dönemde manyetik rezonans görüntüleme (MRG) ile elde edilen beyin omurilik sıvısı (BOS) dinamikleri ve klinik skorlama sistemlerinin karşılaştırılması amaçlanmıştır.

GEREÇ VE YÖNTEM: Ocak 2016 ile Haziran 2020 tarihleri arasında BOS MRG yapılan CM-1 tanılı 21 hasta dâhil edildi. Ayrıca 21 sağlıklı gönüllü değerlendirildi. Tüm hastalara CM-1 ile ilişkili semptomlar nedeniyle dekompresyon cerrahisi uygulanmıştı. 21 hastanın preoperatif MRG bulguları ile klinik bulguları arasındaki ilişki değerlendirildi. Cerrahi uygulanan 21 hastanın klinik ve görüntüleme bulgularındaki değişiklikler karşılaştırıldı.

BULGULAR: Ölçümler serebellar tonsil seviyesinin hemen altından yapıldı. CM-1 hastalarının ameliyat öncesi pik pozitif ve negatif hızları (PPV-PNV) sağlıklı gönüllülerden daha yüksekti (PPV: 6,26 $\pm 2,72$ vs $3,89 \pm 1,74 \mathrm{~cm} / \mathrm{s}, \mathrm{p}=0.001$; PNV: $-7,45 \pm 3,36$ vs $-3,61 \pm 2,65 \mathrm{~cm} / \mathrm{s}$, $\mathrm{p}=0.001)$. CM-1 hastalarının posterior subaraknoid alandan yapılan ölçümde net debi değeri sağlıklı gönüllülere göre daha düşüktü $(\mathrm{p}=0.017)$. Hastaların 13'ünde (\%62) ters akıma bağlı 'aliasing' görüldü. Ameliyat sonrası PPV ve PNV değerleri azaldı (PPV: 6,26 $\pm 2,72$ 'ye karş1 4,73 $\pm 1,94 \mathrm{~cm} / \mathrm{s}, \mathrm{p}=0.017$; PNV: $-7,45 \pm 3,36$ ya karş1 $-4,97 \pm 1,97$, $\mathrm{p}=0.005)$. Net Akıs ise arttı (0.32'ye karşı $2.21 \mathrm{ml} / \mathrm{dak} ; \mathrm{p}=0.053)$. Postoperatif yanit, tonsiller herniasyon derecesi ile ters orantilı idi. Hastalarda Asgari skoru arttıkça, PPV ve PNV değerleri de artmaktadır (sirasiyla $\mathrm{p}=0.003$ ve $\mathrm{p}=0,032$ )

SONUÇ: Bulgularımız, MR görüntüleme kullanılarak elde edilen akış dinamikleri ve morfolojinin klinik bulgularla ilişkili olduğunu, cerrahi ihtiyacı ve zamanlamasını belirlemede yararlı bir araç olabileceğini düşündürmektedir.

Anahtar Kelimeler: Chiari malformasyonu • beyin omurilik sivisı - faz kontrast MRG • kranioservikal dekompresyon • Asgari skoru

${ }^{1}$ Istanbul Medeniyet University, Göztepe Prof. Dr. Süleyman Yalçın City Hospital, Department of Radiology, Istanbul, Turkey

${ }^{2}$ Istanbul Medeniyet University, Göztepe Prof. Dr. Süleyman Yalçın City Hospital, Brain and Neurosurgery Clinic, Istanbul Turkey

Gelis Tarihi / Submitted : Ekim 2021 / Ekim 2021

\footnotetext{
Sorumlu Yazar / Corresponding Author:

Begumhan BAYSAL

Istanbul Medeniyet University, Göztepe Prof. Dr. Süleyman Yalçın City Hospital, Department of

Radiology,Eğitim Neighborhood Fahrettin Kerim Gökay Street, 34722 Kadıköy, Istanbul, Turkey

Phone: +90 2165664000

E-mail: baysalbegumhan@yahoo.com
}

Kabul Tarihi / Accepted : Aralık 2021 / December 2021

\section{Yazar Bilgileri /Author Information:}

Begumhan BAYSAL (ORCID: 0000-0003-0470-1683)

Mahmut Bilal DOGAN (ORCID: 0000-0001-7063-7371) E-mail: mbilaldogan@hotmail.com

Ercan BOSNAK (ORCID: 0000-0001-5026-6884) E-mail: dr.ercanbosnak@gmail.com

Mehmet Sabri GUNDUZ (ORCID:0000-0002-3764-389X) E-mail: mehmetsabrigurbuz@gmail.com Nejat IŞIK (ORCID: 0000-0002-6809-4969) E-mail: dr.nejatisik@gmail.com 


\section{INTRODUCTION}

Chiari malformations are a wide range of diseases that involve an anomaly of hindbrain formation during the development of the central nervous system. Hans Chiari, in his first article on Chiari malformations, described four different types according to the brain structures displaced from the intracranial area. Arnold Chiari malformation type $\mathrm{I}(\mathrm{CM}-1)$ is defined as a $5 \mathrm{~mm}$ or more inferior extension of the cerebellar tonsils from the level of the foramen magnum (FM) (1).

In radiological studies conducted for different reasons, $\mathrm{CM}$ is seen at a rate of approximately $1 \%$. Most of them (90\%) are asymptomatic and there is not enough information about the long-term natural course (2). The degree of tonsillar herniation shown by imaging alone in Chiari I malformation is not sufficient to explain the severity of clinical symptoms and does not directly correlate with symptoms (3).

In addition, the timing and criteria of surgical intervention in the treatment of Chiari I malformation are controversial. The adequacy of surgical treatment can be followed by the incomplete recovery of symptoms and signs after surgery, or it can be measured by the reflection of clinical relief on imaging (4).

Therefore many studies on CM1 have focused on cerebrospinal fluid (CSF) dynamics (4-6). The CSF volume $(\mathrm{mL} / \mathrm{min})$ that moves up or down the foramen magnum is associated with the changing cerebral blood volume during the cardiac cycle. The CSF flow velocity (in $\mathrm{cm} / \mathrm{s}$ ) at the foramen magnum level depends more on the CSF distance and the shape of this area. Any condition that restricts passage within the foramen magnum affects the flow volume and flow velocity (7). Consequently; tonsil herniation, foramen magnum volume, or interventions affecting foramen capacity are expected to affect CSF volume and peak CSF velocity.

In the literature, the altered CSF flow kinetics in Chiari malformation causes signs and symptoms of the disease (8). Phase-contrast Magnetic Resonance (PC MR) studies show the jet flows at the foramen level, heterogeneity in CSF motion, and bi-directional CSF flow. PC MR is also used to demonstrate changes in CSF flow dynamics, CSF flow patterns, and quantitative measurement during each cardiac cycle.

In this study, we evaluated the differences in CSF flow dynamics in the subarachnoid spaces (SAS) in the anterior cervical and posterior cervical, normal control subjects, and patients with CM-1 before and after surgery on axial MR imaging. We aimed to investigate the differences of cerebrospinal fluid (CSF) dynamics obtained by MR imaging in Chiari Malformation Type-1 patients at the preoperative and postoperative period and its relationship with clinical scoring systems.

\section{Abbreviations}

CM-1: Chiari malformation type I

CSF: Cerebrospinal fluid
PC MR: Phase contrast Magnetic Resonance

FM: Foramen magnum

\section{MATERIAL AND METHOD \\ Study Population and Definitions}

This retrospective study was carried out in a tertiary care center. Medical records of the hospital for the timeline from January 2016 to December 2020, were reviewed retrospectively.

We noted clinical presentation, neuroimaging findings, surgery, postoperative data, and outcome. Prior to data collection, the Institutional Review Board at our hospital approved the study (Decision number: 2020/0016).

Inclusion criteria were determined as compliance with the following criteria: 1 . The MRI, including Phase Contrast sequences, of the patient must be taken at the center of conduct of this research. 2. Sufficient image quality to allow flow dynamics, 3. Tonsillar herniation length 5 $\mathrm{mm}$ or more, 4. Patients who have undergone or planned decompression surgery. Criteria for exclusion were set as 1. Patients operated at the research center, but imaging was done in another center, 2. Pediatric population.

The 21 patients diagnosed with Chiari-1 and 21 healthy control groups who underwent CSF MRI were evaluated. (Figure 1) All volunteers in the control group declared that they were in good health and had no current or previous spinal or neurological problems. All the patients underwentdecompression surgery due to Chiari malformation.

Clinical information and scores were recorded on a worksheet by the surgical team who were blind to the radiology data. The Asgari score, which measures two different components as cranial nerve involvement and spinal cord dysfunction, was used to evaluate the clinical condition of the patients at the time of first admission (9).

\section{MRI Protocol}

MR imaging was performed with two different devices (1.5 Tesla GE Optima MR450w and MR360 (General Electric, Chicago, Illinois, USA)). The imaging protocol included the T1W and T2W scans and cine velocity encoded phase contrast scans, with low-velocity encoding $(5-20 \mathrm{~cm} / \mathrm{s})$ for imaging the CSF flow at the foramen magnum region. Other typical imaging parameters were matrix $128 \times 128$, FOV $250 \times 250 \mathrm{~mm}$, TR/TE $300 / 80 \mathrm{~ms}$, and slice thickness of $6 \mathrm{~mm}$.

\section{Phase Contrast Magnetic Resonance and Analysis}

The axial section position was chosen as the foramen magnum in normal volunteers. For the patients, the section was placed just below the tonsils where the CSF flow was sufficiently visible. (Figure 2) CSF flow data were obtained along with the anterior and posterior subarachnoid space by region of interest (ROI) placement. (Figure 3) 


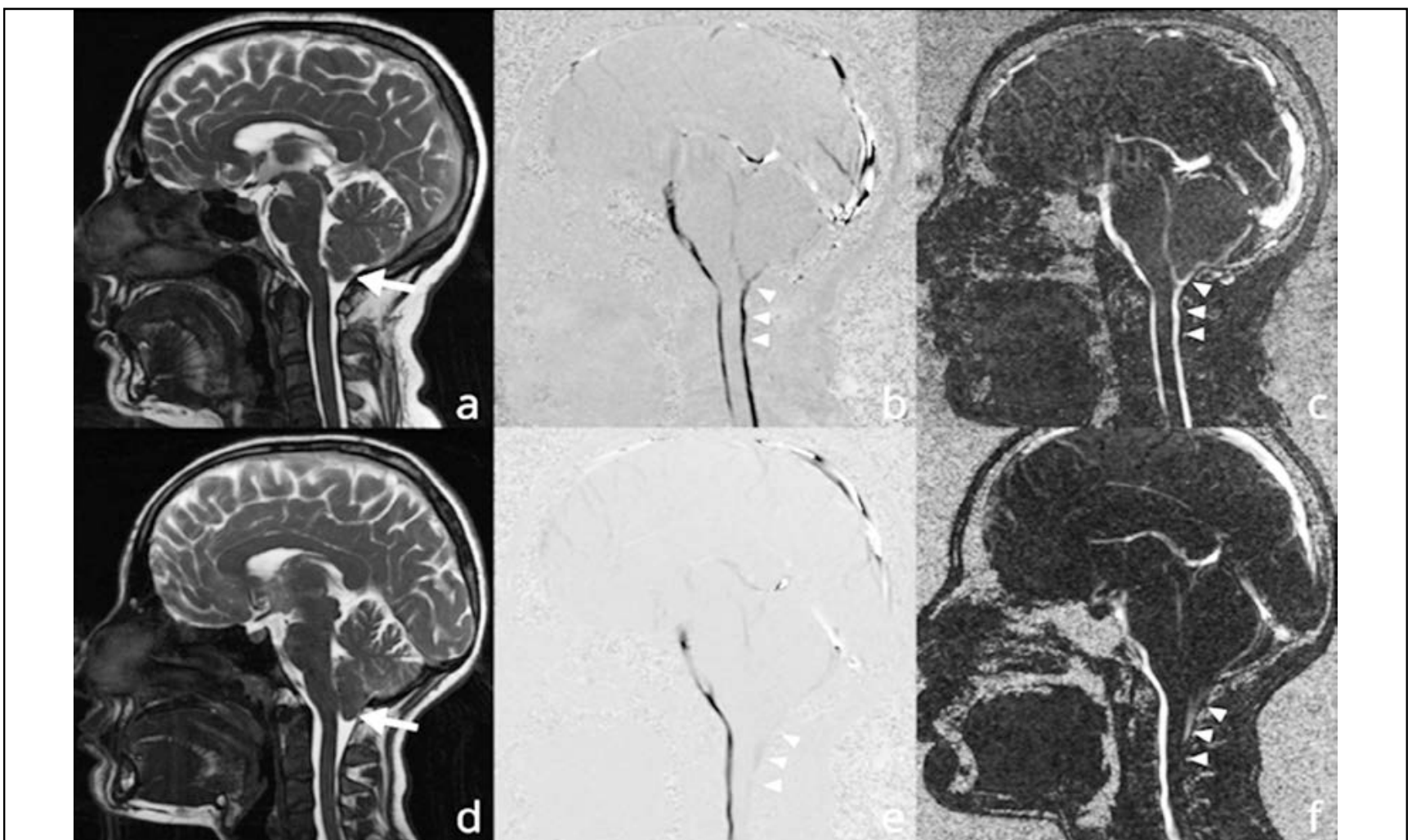

Fig 1. a. Normally located cerebellar tonsil seen with the arrow on midline sagittal T2 image from a healthy volunteer. b, c. Phase contrast and magnitude MRI images showing normal CSF flow marked with arrowheads. d. Caudally located cerebellar tonsil seen with the arrow on midline sagittal T2 image in Chiari 1 patient. e, f. Phase contrast and magnitude MRI images showing reduced CSF flow, marked with arrowheads posteriorly.

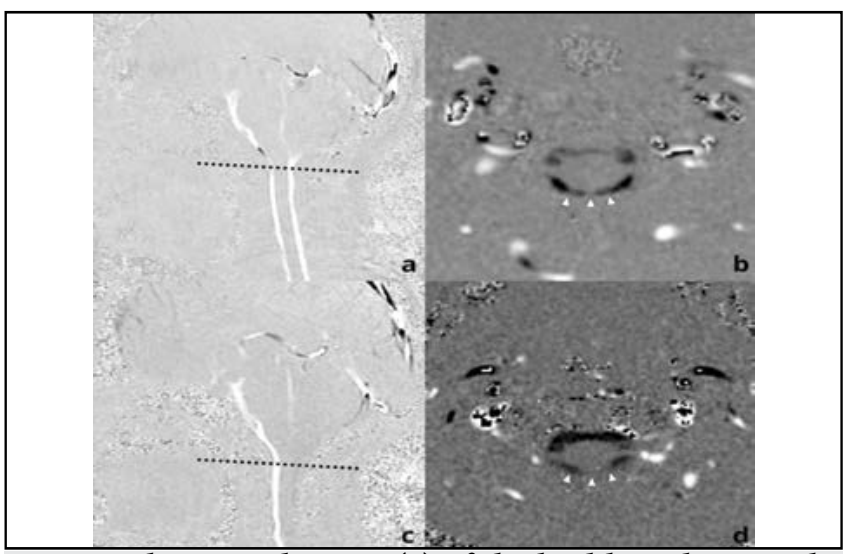

Fig 2. In the sagittal image (a) of the healthy volunteer, the level of the axial phase contrast (b) image taken just below the descending tonsil tip is marked with a dot-by-dot pattern. Normal flow in the posterior subarachnoid space at this level is shown with arrowheads. Similarly, the sagittal phase contrast (c) image and the level of axial phase contrast (d) are shown in Chiari 1 patient. Reduced flow in the posterior subarachnoid space at this level is shown with arrowheads.

Thirty-two image frames were regularly acquired with the wave from a fingertip electrode used for the pulse-gate.

Flow analysis was conducted with commercially available ReportCard software on the GE image processing station

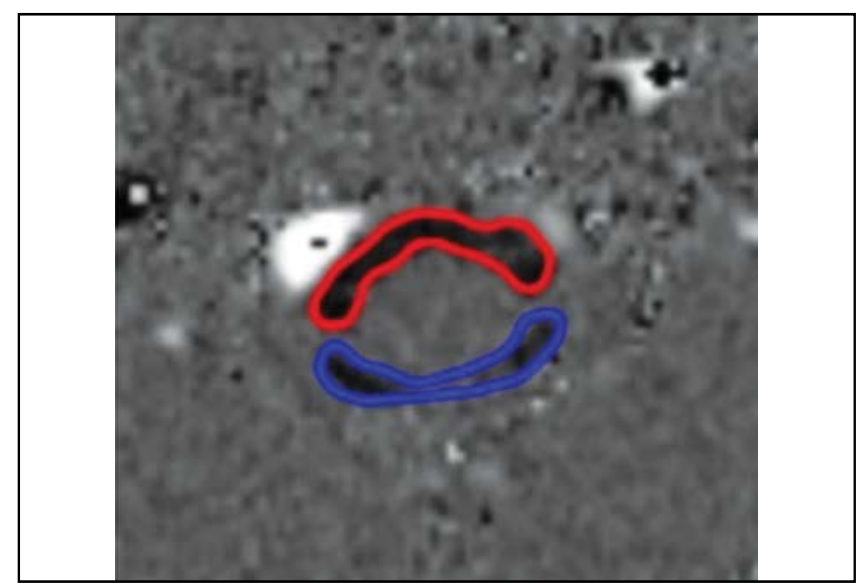

Fig 3. Image of red and blue ROIs, respectively, placed in the anterior and posterior subarachnoid spaces.

(AW VolumeShare 7). The software calculated the flow and velocity in each voxel in the region of interest.

CSF dynamics were measured preoperatively and after 1 month to 1 year postoperatively to see the changes in CSF flow. The relation between preoperative MR findings and the clinic of all 21 patients included in the study was evaluated. The changes in clinical and imaging findings of 21 patients who have been operated on so far were compared. 


\section{Surgical Technique}

Surgical Indications and Technique: After explaining the risks and benefits of the surgery, informed consent was obtained from the patients. Then we performed craniocervical decompression in symptomatic patients. The indications for decompressive CM surgery were symptoms like headache, myelopathic symptoms, paresthesias, syringomyelia, and scoliosis, which were consistent with published reports in similar populations $(10,11)$. Standard decompression surgery was performed on CM-1 patients.

\section{Follow-up and Outcomes}

Neurological examination and radiological imaging were performed on the first postoperative day. The patients were followed up every three months for the first year, and then at annual intervals, adding neurophysiological tests if necessary. The outcome of surgery was evaluated by the improvement in the neurological findings of the patients and their lifestyles $(12,13)$.

\section{Statistical Analysis}

Mean, standard deviation (SD), and the correlation coefficient were calculated for each group of patients and healthy subjects using SPSS software version 23 (IBM SPSS Inc., Chicago, Illinois, United States). Postoperative changes in CSF dynamic values of the patients were compared using the Wilcoxon Signed-Rank test. The relationship of dynamic CSF values with clinical scores was examined with Spearman's correlation analysis. Pearson chi-square test and Fisher's exact test were used to comparing qualitative data. The p-value of 0.05 was considered statistically significant.

\section{RESULTS}

\section{Patient Characteristics and Clinical Presentation}

Twenty-seven female and fifteen male participants were included in this study. The mean age at diagnosis was 37.8 years (range 18-65 years). The mean symptom duration of the patients included in the study ranged from 1 month to 9 years (mean: 24 months). The follow-up period was between 1 and 5 years. Suboccipital headache (95.2\%), numbness in upper extremities (61.9\%), disability in upper extremities (14.3\%), disability in lower extremities (33.3\%), loss of sensation (33.3\%), difficulty swallowing (19.1\%) were the most relevant clinical features. Other findings including syringomyelia and basilar invagination are summarized in Table 1.

\section{MRI Findings}

In the patients, it was found that the cerebellar tonsil herniated from the foramen magnum in the mean of $12.5 \mathrm{~mm}$ in midline sagittal MRI. There is a statistically significant positive correlation between the Asgari scale and tonsillar herniation (the Asgari scale increases as the herniation increases) $(\mathrm{p}<0.01)$. As the Asgari score of the cases increases, the Peak Positive and Negative Velocity Anterior values also increase with a statistically significant correlation ( $\mathrm{p}=0.003 ; \mathrm{p}=0,032$ respectively). There is a negative relationship between the Asgari scale and net flow, but it is not statistically significant. There was no correlation between other dynamic values of CSF and clinical score.

At the end of cerebellar tonsil level peak positive and negative velocity (PPV-PNV) of CM-1 patients were higher than healthy volunteers pre-surgery. Preoperative net flow in the posterior subarachnoid space of CM-1 patients was lower than in healthy volunteers $(\mathrm{p}=0.017)$. (Table 2) Preop 'Positive Pixel Flow Anterior' value of CM-1 patients were higher than control group also $(\mathrm{p}<0.01)$.

PPV and PNV were decreased after surgery $(\mathrm{p}=0.017$ and $\mathrm{p}=0.005$ respectively). Positive and Negative Pixel Flow was decreased in the anterior segment $(p=0.005$ and $\mathrm{p}=0.035$ respectively). (Figure 4 ) (Table 3 )

\section{Table 1. General descriptive characteristics and symptoms of the cohort}

\begin{tabular}{|c|c|c|}
\hline & Chiari-I $N=21$ & Control $N=21$ \\
\hline Age (Median) & $38(18 ; 56)$ & $35(18 ; 67)$ \\
\hline \multicolumn{3}{|l|}{ Gender: } \\
\hline Female & $11(52.4 \%)$ & $16(76.2 \%)$ \\
\hline Male & $10(47.6 \%)$ & $5(23.8 \%)$ \\
\hline \multicolumn{3}{|l|}{ Symptoms: } \\
\hline Duration 1 & 1 month -9 years & \\
\hline Suboccipital headache & $20(95.2 \%)$ & \\
\hline Numbness in upper extremities & $13(61.9 \%)$ & \\
\hline Disability in upper extremities & $3(14.3 \%)$ & \\
\hline Disability in lower extremities & $7(33.3 \%)$ & \\
\hline Loss of sensation ${ }^{2}$ & $7(33.3 \%)$ & \\
\hline Difficulty swallowing & $4(19.1 \%)$ & \\
\hline Asgari Score & $3.7(1 ; 8)$ & \\
\hline \multicolumn{3}{|l|}{ Additional findings: } \\
\hline Syringomyelia & $8(38.1 \%)$ & \\
\hline Basilar invagination & $6(28.6 \%)$ & \\
\hline
\end{tabular}


The Net Flow was increased in the posterior segment postoperatively $(p=0.053)$. While CSF flow was observed nonhomogeneous in the patient group, it was homogeneous in the control group.

Aliasing of the reverse flow was seen in 13 (62\%) patients.

Table 2. CSF ${ }^{1}$ dynamics of samples

\begin{tabular}{|c|c|c|c|}
\hline Variable & Normal & $C M-1^{2}$ & $p$ \\
\hline Preoperative Tonsiles Herniation (mm) & - & $12.61 \pm 4.7$ & \\
\hline \multicolumn{4}{|l|}{ Velocity Anterior } \\
\hline Peak Positive Velocity Anterior $\left(\right.$ Mean $\left.\pm \mathrm{SD}^{3}, \mathrm{~cm} / \mathrm{sec}\right)$ & $3,89 \pm 1,74$ & $6,26 \pm 2,72$ & 0.001 \\
\hline Peak Negative Velocity Anterior (Mean $\pm \mathrm{SD}, \mathrm{cm} / \mathrm{sec}$ ) & $3,61 \pm 2,65$ & $7,45 \pm 3,36$ & 0.001 \\
\hline \multicolumn{4}{|l|}{ Velocity Posterior } \\
\hline Peak Positive Velocity Posterior (Mean \pm SD, cm/sec) & $3,31 \pm 1,21$ & $4,02 \pm 2,22$ & 0.421 \\
\hline Peak Negative Velocity Posterior $($ Mean $\pm S D, \mathrm{~cm} / \mathrm{sec})$ & $3,67 \pm 2,06$ & $4,16 \pm 1,41$ & 0.170 \\
\hline \multicolumn{4}{|l|}{ Flow } \\
\hline Net Flow Anterior (Mean \pm SD, ml/min) & $2,60 \pm 5,24$ & $3,84 \pm 9,96$ & 0.618 \\
\hline Net Flow Posterior $($ Mean $\pm S D, \mathrm{ml} / \mathrm{min})$ & $3,67 \pm 4,71$ & $0,32 \pm 3,97$ & 0.017 \\
\hline \multicolumn{4}{|l|}{ Pixel Flow Anterior } \\
\hline Positive Pixel Flow Anterior (Mean \pm SD, ml/min) & $17,66 \pm 6,15$ & $23,03 \pm 9,43$ & 0.001 \\
\hline Negative Pixel Flow Anterior (Mean \pm SD, $\mathrm{ml} / \mathrm{min})$ & $-15,05 \pm 5,60$ & $-19,18 \pm 9,06$ & 0.084 \\
\hline \multicolumn{4}{|l|}{ Pixel Flow Posterior } \\
\hline Positive Pixel Flow Posterior (Mean \pm SD, ml/min) & $12,42 \pm 5,89$ & $9,59 \pm 5,18$ & 0.106 \\
\hline Negative Pixel Flow Posterior (Mean $\pm \mathrm{SD}, \mathrm{ml} / \mathrm{min})$ & $-8,74 \pm 4,39$ & $-9,26 \pm 6,68$ & 0.767 \\
\hline
\end{tabular}

Table 3. Post-operative changes of $\mathrm{CSF}^{1}$ dynamics

\begin{tabular}{|c|c|c|c|}
\hline Variable & CM-1 Pre ${ }^{2}$ & CM-1 Post ${ }^{3}$ & $p$ \\
\hline \multicolumn{4}{|l|}{ Velocity Anterior } \\
\hline Peak Positive Velocity Anterior $\left(\right.$ Mean $\left.\pm \mathrm{SD}^{4}, \mathrm{~cm} / \mathrm{sec}\right)$ & $6.24 \pm 2.79$ & $4.82 \pm 1.94$ & 0.017 \\
\hline Peak Negative Velocity Anterior (Mean $\pm \mathrm{SD}, \mathrm{cm} / \mathrm{sec})$ & $7.53 \pm 3.43$ & $5.11 \pm 1.92$ & 0.005 \\
\hline \multicolumn{4}{|l|}{ Velocity Posterior } \\
\hline Peak Positive Velocity Posterior (Mean \pm SD, cm/sec) & $4.14 \pm 2.21$ & $3.74 \pm 1.52$ & 0.931 \\
\hline Peak Negative Velocity Posterior $($ Mean \pm SD, $\mathrm{cm} / \mathrm{sec})$ & $4.26 \pm 1.37$ & $3.39 \pm 1.33$ & 0.131 \\
\hline \multicolumn{4}{|l|}{ Flow } \\
\hline Net Flow Anterior (Mean $\pm \mathrm{SD}, \mathrm{ml} / \mathrm{min})$ & $3.55 \pm 10.13$ & $2.04 \pm 6.14$ & 0.533 \\
\hline Net Flow Posterior $($ Mean $\pm \mathrm{SD}, \mathrm{ml} / \mathrm{min})$ & $0.26 \pm 4.06$ & $2.15 \pm 3.42$ & 0.053 \\
\hline \multicolumn{4}{|l|}{ Pixel Flow Anterior } \\
\hline Positive Pixel Flow Anterior (Mean \pm SD, ml/min) & $23,03 \pm 9,43$ & $18,24 \pm 6,01$ & 0.035 \\
\hline Negative Pixel Flow Anterior (Mean $\pm \mathrm{SD}, \mathrm{ml} / \mathrm{min})$ & $-19,18 \pm 9,06$ & -15.896 .91 & 0.050 \\
\hline \multicolumn{4}{|l|}{ Pixel Flow Posterior } \\
\hline Positive Pixel Flow Posterior (Mean $\pm \mathrm{SD}, \mathrm{ml} / \mathrm{min}$ ) & $9,59 \pm 5,18$ & $9,84 \pm 4,82$ & 0.858 \\
\hline Negative Pixel Flow Posterior (Mean \pm SD, ml/min) & $-9,26 \pm 6,68$ & $-7,63 \pm 3,88$ & 0.291 \\
\hline $\begin{array}{l}{ }^{1} \text { CSF: Cerebrospinal fluid } \\
{ }^{2} \text { CM-1: Chiari malformation type 1, preoperative } \\
{ }^{3} \text { CM-1: Chiari malformation type 1, postoperative } \\
{ }^{4} \text { SD: Standart deviation }\end{array}$ & & & \\
\hline
\end{tabular}


Table 4. CSF$^{1}$ dynamics and clinical scores

\begin{tabular}{|c|c|c|}
\hline \multirow{2}{*}{ Variable } & \multicolumn{2}{|c|}{ Asgari Score } \\
\hline & $r$ & $p$ \\
\hline \multicolumn{3}{|l|}{ Preoperative Velocity } \\
\hline Peak Positive Velocity Anterior $\left(\right.$ Mean $\left.\pm \mathrm{SD}^{2}, \mathrm{~cm} / \mathrm{sec}\right)$ & ${ }^{\ddagger} 0,452$ & 0,003 \\
\hline Peak Negative Velocity Anterior (Mean $\pm \mathrm{SD}, \mathrm{cm} / \mathrm{sec}$ ) & ${ }^{\dagger}-0,331$ & 0,032 \\
\hline Peak Positive Velocity Posterior (Mean $\pm \mathrm{SD}, \mathrm{cm} / \mathrm{sec}$ ) & ${ }^{\ddagger} 0,017$ & 0,916 \\
\hline Peak Negative Velocity Posterior $($ Mean $\pm S D, \mathrm{~cm} / \mathrm{sec})$ & ${ }^{*}-0,113$ & 0,474 \\
\hline \multicolumn{3}{|l|}{ Postoperative Velocity } \\
\hline Peak Positive Velocity Posterior $($ Mean $\pm \mathrm{SD}, \mathrm{cm} / \mathrm{sec})$ & $-0,026$ & 0,912 \\
\hline Peak Negative Velocity Posterior (Mean \pm SD, $\mathrm{cm} / \mathrm{sec}$ ) & 0,232 & 0,312 \\
\hline Peak Positive Velocity Posterior (Mean \pm SD, $\mathrm{cm} / \mathrm{sec}$ ) & 0,119 & 0,608 \\
\hline Peak Negative Velocity Posterior $($ Mean $\pm \mathrm{SD}, \mathrm{cm} / \mathrm{sec})$ & $-0,240$ & 0,294 \\
\hline \multicolumn{3}{|l|}{ Preoperative Flow } \\
\hline Net Flow Anterior $($ Mean $\pm \mathrm{SD}, \mathrm{ml} / \mathrm{min})$ & ${ }^{\dagger}-0,080$ & 0,616 \\
\hline Net Flow Posterior (Mean $\pm \mathrm{SD}, \mathrm{ml} / \mathrm{min})$ & ${ }^{*}-0,281$ & 0,071 \\
\hline \multicolumn{3}{|l|}{ Postoperative Flow } \\
\hline Net Flow Anterior $($ Mean $\pm \mathrm{SD}, \mathrm{ml} / \mathrm{min})$ & 0,137 & 0,552 \\
\hline Net Flow Posterior (Mean \pm SD, ml/min) & $-0,179$ & 0,438 \\
\hline
\end{tabular}

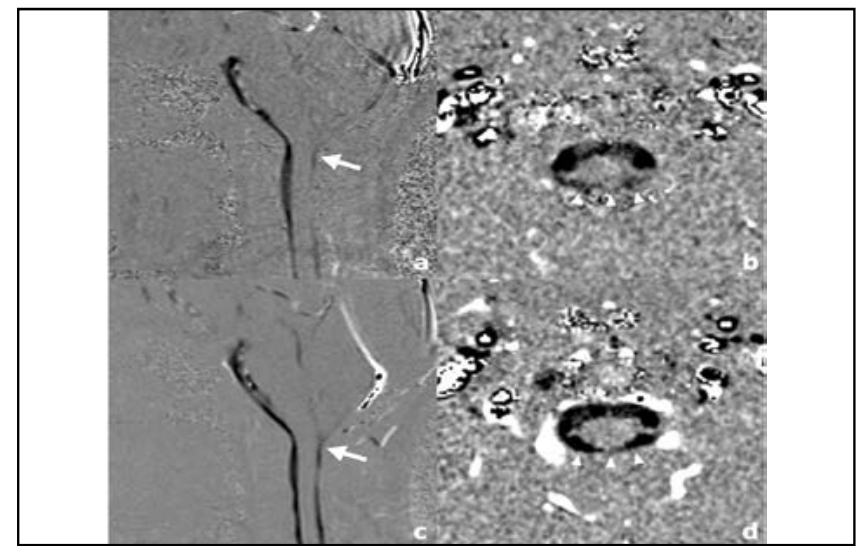

Fig 4. a, b. The images are the phase-contrast images taken from the patient in the sagittal and axial planes in the preoperative period (arrow and arrowheads). $c$, d. Images from the same patient show the relative change in CSF flow after decompression (arrow and arrowheads).

\section{DISCUSSION}

In this study, a correlation was shown between the degree of tonsillar herniation and symptoms, while not showing a significant relationship between the flow rate of CSF and the degree of symptoms. We found that the maximum CSF velocities were higher in CM-1 patients below the cerebellar tonsillar level compared to the control group (14). The positive and negative peak velocities decreased and net flow increased after craniocervical decompression surgery in CM1 patients. These results support the abnormal CSF flow pattern in CM1 patients (15-17).
In CM-1 patients, the maximum systolic and diastolic velocities were $6.26 \pm 2.72$ and $7.45 \pm 3.36(\mathrm{~cm} / \mathrm{s})$, respectively. These values are similar to those of Gholampour et al (5). However, many ranges below and above these values have been reported in the literature $(6,7,18)$. The reason for this wide range can be thought to be that the level of measurement, the ROI area, and the devices are different. The net flow rate was found to be $0.32 \mathrm{ml} / \mathrm{min}$ in the patient group. Contrary to the variability of the CSF velocity, it is found that the velocity values after decompression decrease in almost all studies in the literature $(15,19)$.

There is a statistically significant positive correlation between the Asgari scale and tonsillar herniation (the Asgari scale score increases as the herniation increases). As the Asgari score of the cases increases, the Peak Positive and Negative Velocity Anterior values also increase The reason for this is the difficulty of CSF flow in the posterior subarachnoid space in patients with increased tonsillar herniation. While this increases the symptoms, it also shifts the CSF flow anteriorly. With the widening of the posterior subarachnoid space after surgery, the net flow increased and approached normal. As a result of the posterior shift of the flow, the peak velocity values decreased and approached normal in the anterior.

Statistically significant changes and a correlation were found in clinical scores and CSF MRI flow values before and after surgery. This is the first study to be conducted in this context, aiming to reconcile the quantitative MR findings with the quantitative values obtained by examination. 
Our most important limitation was that the measurement location and technique of CSF dynamics differed between studies. The retrospective clinical scoring and the limited number of operated patients are other weaknesses.

\section{CONCLUSION}

Today, the presence and severity of signs and symptoms are decisive for surgical intervention in Arnold Chiari malformation type I. MRI, on the other hand, plays an increasingly effective role in patient management, as in many other diseases. Our findings suggest that the determination of flow dynamics and morphology using MRI findings correlates with clinical findings and may be a useful tool in determining the need and timing of surgery.

Declarations of interest: none

Funding: The authors received no specific funding for this manuscript.

Makalenin özeti, Türk Nöroradyoloji Derneği'nin uluslararası katılımlı 30. Yıl Yillık Toplantısı'nda 'Araştırma Sunumu' olarak sunulmuş ve Neuroradiology dergisinde online olarak yayınlanmıștır.

Çıkar çatışması beyanı: Yoktur. Finansman: Yazarlar bu makale için özel bir fon almamıştır.

\section{REFERENCES}

1) Chiari H. Concerning alterations in the cerebellum resulting from cerebral hydrocephalus. Pediat Neurosci. 1987; 13: 3-8. https://doi.org/10.1159/000120293

2) Meadows J, Kraut M, Guarnieri M, et al. Asymptomatic Chiari Type I malformations identified on magnetic resonance imaging. J Neurosurg. 2000; 92: 920-6. https://doi.org/10.3171/jns.2000.92.6.0920 3) Milhorat TH, Chou MW, Trinidad EM, et al. Chiari I malformation redefined: clinical and radiographic findings for 364 symptomatic patients. Neurosurgery. 1999; 44: 1005-17. https://doi.org/10.1097/00006123-199905000-00042

4) Iskandar BJ, Quigley M, Haughton VM. Foramen magnum cerebrospinal fluid flow characteristics in children with Chiari I malformation before and after craniocervical decompression. J Neurosurg. 2004; 101: 169-78.

https://doi.org/10.3171/ped.2004.101.2.0169

5) GholampourS, Gholampour H. Correlation of a newhydrodynamic index with other effective indexes in Chiari I malformation patients with different associations. Sci Rep. 2020; 10: 15907.

https://doi.org/10.1038/s41598-020-72961-0

6) Wang CS, Wang X, Fu CH, et al. Analysis of cerebrospinal fluid flow dynamics and morphology in Chiari I malformation with cine phase-contrast magnetic resonance imaging. Acta Neurochir. 2014;1 56: 707-13. https://doi.org/10.1007/s00701-013-1958-8

7) Gholampour S, Taher M. Relationship of Morphologic Changes in the Brain and Spinal Cord and Disease Symptoms with Cerebrospinal Fluid Hydrodynamic Changes in Patients with Chiari Malformation Type I. World Neurosurg. 2018; 116: e830-9.

https://doi.org/10.1016/j.wneu.2018.05.108

8) Sadique SI, Pandey P, Chaudhuri AK. Cerebrospinal Fluid Flowmetry in Pediatric Patients with Chiari Malformation I with Surgical Implications. World Neurosurg. 2020; 135: e83-6.

https://doi.org/10.1016/j.wneu.2019.10.184

9) Asgari S, Engelhorn TM, Bschor M, et al. Surgical prognosis in hindbrain related syringomyelia. Acta Neurol Scand. 2003; 107: 12-21. https://doi.org/10.1034/j.1600-0404.2003.01357.x

10) McGirt MJ, Attenello FJ, Atiba A, et al. Symptom recurrence after suboccipital decompression for pediatric Chiari I malformation: analysis of 256 consecutive cases. Childs Nerv Syst. 2008; 24: 1333-9. https://doi.org/10.1007/s00381-008-0651-3

11) Leon TJ, Kuhn EN, Arynchyna AA, et al. Patients with "benign" Chiari I malformations require surgical decompression at a low rate. J Neurosurg Pediatr. 2019; 23: 498-506.

https://doi.org/10.3171/2018.10.PEDS18407

12) Aliaga L, Hekman KE, Yassari R, et al. A novel scoring system for assessing Chiari malformation type I treatment outcomes. Neurosurgery. 2012; 70: 656-64.

https://doi.org/10.1227/NEU.0b013e31823200a6

13) Yarbrough CK, Greenberg JK, Smyth MD, et al. External validation of the Chicago Chiari Outcome Scale. J Neurosurg Pediatr. 2014; 13: 679-84. https://doi.org/10.3171/2014.3.PEDS13503

14) Yilmaz A, Kanat A, Musluman AM, et al. When is duraplasty required in the surgical treatment of Chiari malformation type I based on tonsillar descending grading scale? World Neurosurg. 2011; 75: 307-13. https://doi.org/10.1016/j.wneu.2010.09.005

15) Clarke EC, Stoodle MA, Bilston LE. Changes in temporal flow characteristics of CSF in Chiari malformation Type I with and without syringomyelia: implications for theory of syrinx development. J Neurosurg. 2013; 118: 1135-40. https://doi.org/10.3171/2013.2.JNS12759 16) Dolar MT, Haughton VM, Iskandar BJ, et al. Effect of craniocervical decompression on peak CSF velocities in symptomatic patients with Chiari I malformation. Am J Neuroradiol. 2004; 25: 142-5.

17) Haughton VM, Korosec FR, Medow JE, et al. Peak systolic and diastolic CSF velocity in the foramen magnum in adult patients with Chiari I malformations and in normal control participants. Am J Neuroradiol. 2003; 24: 169-76.

18) Linge SO, Mardal KA, Helgeland A, et al. Effect of craniovertebral decompression on CSF dynamics in Chiari malformation type I studied with computational fluid dynamics: Laboratory investigation. J Neurosurg Spine. 2014; 21: 559-64. https://doi.org/10.3171/2014.6.SPINE13950

19) Liu B, Wang ZY, Xie JC, et al. Cerebrospinal fluid dynamics in Chiari malformation associated with syringomyelia. Chin Med J. 2007; 120:219-23.

Ankara Eğt. Arş. Hast. Derg. (Med. J. Ankara Tr. Res. Hosp.), 2021 ; 54(3) : 412-418

S.B. İstanbul Medeniyet Üniversitesi Göztepe Eğitim ve Araştırma Hastanesi Klinik Araştırmalar Etik Kurulu'nun 29.01.2020 tarih ve 2020/0016 sayılı izni ile yürütülmüștür. 